Article

\title{
Devising a Competence-Based Training Program for Educators of Sustainable Development: Lessons Learned
}

\author{
Paul Vare ${ }^{1, *}$, Grete Arro ${ }^{2}$, Andre de Hamer ${ }^{3}$, Giovanna Del Gobbo ${ }^{4,5}$, Gerben de Vries ${ }^{3}$, \\ Francesca Farioli ${ }^{5}$, Chrysanthi Kadji-Beltran ${ }^{6}$, Mihkel Kangur ${ }^{2}$, Michela Mayer ${ }^{5}$, \\ Rick Millican ${ }^{1}$, Carlien Nijdam ${ }^{3}$, Monika Réti ${ }^{7}$ and Aravella Zachariou ${ }^{6}{ }^{[}$ \\ 1 School of Education, University of Gloucestershire, Francis Close Hall, Cheltenham GL50 4AZ, UK; \\ rmillican@glos.ac.uk \\ 2 Institute of Ecology, Tallinn University, 10120 Tallinn, Estonia; arro@tlu.ee (G.A.); \\ mihkel.kangur@tlu.ee (M.K.) \\ 3 Duurzame PABO, Sint Kruis 4528 KH, The Netherlands; andredehamer@duurzamepabo.nl (A.d.H.); \\ gjdevr@gmail.com (G.d.V.); carlien.nijdam@hz.nl (C.N.) \\ 4 Department of Education, Languages, Interculture and Psychology, University of Florence, 50121 Florence, \\ Italy; giovanna.delgobbo@unifi.it \\ 5 Italian Association of Sustainability Science (IASS), 00184 Rome, Italy; francesca.farioli@gmail.com (F.F.); \\ michela.mayer@gmail.com (M.M.) \\ 6 Department of Education, School of Education and Social Sciences, Frederick University, Nicosia 1036, \\ Cyprus; edrda@yahoo.com (C.K.-B.); aravella@cytanet.com.cy (A.Z.) \\ 7 Hungarian Research Teachers' Association, Budapest 1363, Hungary; retimon@gmail.com \\ * Correspondence: pvare@glos.ac.uk
}

Received: 28 February 2019; Accepted: 18 March 2019; Published: 29 March 2019

\begin{abstract}
Over recent decades, education policy has been preoccupied with economic growth while paying insufficient heed to global sustainability challenges. International initiatives to promote education for sustainable development (ESD) have been hampered by a lack of clarity on how to implement this form of education. To address this concern, a Rounder Sense of Purpose (RSP) began as a three-year EU-funded project that set out to develop a practical accreditation model for educators working on ESD. Expert and user opinion was sought through several rounds of structured consultation with over 500 people, chiefly using a Delphi approach, to develop and validate the model. The resulting framework comprises 12 competences, each with three learning outcomes and several underpinning components. This is supported by a range of activities largely reflecting a constructivist pedagogy. A range of assessment techniques have also been piloted within the project although this remains an area for further enquiry. Ultimately, it was decided not to design a single qualification template because defining the award to such a level of detail would make it more difficult to apply across multiple jurisdictions. Partners also felt that such an approach would atomize learning in a way that runs counter to the holistic principles of sustainability. RSP provided a rich learning experience for those involved and has already demonstrated its potential to extend its impact well beyond the original participants.
\end{abstract}

Keywords: Competences; ESD; teacher education; competence framework

\section{Introduction}

For over 30 years, education reform globally has been characterized by increasing standardization and a "narrowing of what counts as curriculum" [1] (p. 35). Education policy has been preoccupied 
with economic growth while paying insufficient heed to the way in which wealth is distributed, with one percent of the global population now having more wealth than the remaining 99\% combined [2]. Perhaps even more alarmingly, this economic growth is predicated on the exploitation of finite resources, the generation of toxic waste and changes to the planet's biodiversity and climate on a scale that threatens our survivability.

The long-standing mismatch between these global challenges and the lack of a coherent educational policy response has stimulated decades of international initiatives to enhance or re-define education. Indeed, education is seen as "a critical tool in the transformation towards sustainability" [3] (p. 600). Such transformation requires teachers who have a good grasp of pressing sustainability challenges and who can effectively engage their students in processes of positive societal change [4]. Efforts to reorient education in this way face at least two critical drawbacks: firstly, a lack of conceptual clarity, with labels ranging from "environmental education" to "learning for sustainability" to "education for sustainable development" (ESD), each being interpreted differently by a range of actors. Secondly, the practical implications of these ideas are not clear for most education professionals who are invited to adopt them.

It is the second of these concerns that inspired the project, a Rounder Sense of Purpose (RSP), which set out to develop and test a framework of educator competences that could contribute to achieving a more sustainable world. The project name deliberately invokes the challenge of promoting a more holistic vision of education while avoiding the trap of limiting this in the minds of education professionals to something that is about sustainable development rather than education itself. The first phase of the RSP project ran for three years between 2015 and 2018. Funded under the European Union Erasmus+ program, the project partners were the University of Gloucestershire (UK), Frederick University (Cyprus), the Hungarian Research Teachers' Association, the Italian Association for Sustainability Science, Duurzame PABO (The Netherlands) and Tallinn University (Estonia). The project set out to develop a pan-European qualification although this soon appeared to be unattainable and so the focus shifted to the components, principally the competences, that might underpin a qualification in education for sustainable development (ESD) in any context.

This paper explains the background to the RSP project, provides brief examples of its action research approach, reports on its outputs, and concludes with areas for further research that are currently the focus of a second project phase.

\section{Background}

\subsection{Defining Competence}

The literature on competences, and that related to sustainability competences in particular, reveals a degree of conceptual ambiguity as the term competence is associated with skills, abilities, capabilities, capacities, qualifications, and other concepts. Competences are seen as a complex of knowledge, skills, and attitudes that enable successful task performance and problem solving [5]. For the teacher, competences help them to become able to perform better and more effectively under different circumstances, frameworks and conditions [6-8]. What is required therefore is not the mere achievement of educational goals, but what makes teachers able to meet those goals $[9,10]$. According to Weinert [11] competences are the positive combination of an individual's knowledge, ability, and willingness to cope successfully and responsibly with changing situations. Competences are not therefore simply concerned with teachers' ability to meet visible goals but also extend to characteristics that are not immediately obvious yet which might be identified in teachers' behavior.

For Rost [12], competences cannot be communicated but must be developed, they are not taught but they are learned. Similarly, Sleurs [13] defines competence as "... not what should be taught, but what should be learned, what abilities are needed for acting, which concepts and problem-solving strategies people should have acquired" (ibid: 40). This internalizing quality is emphasized by Barth et al. [14] who understand competences as the interaction between the cognitive construction 
of mental models and non-cognitive components, citing the concept of value interiorization. The acquisition or development of competence is, in essence, a process by which teachers can demonstrate behaviors and attitudes beyond their inherent abilities and represent internal as well demonstrable behavioral elements. Furthermore, competence itself is not an end state but a quality that is developed continually through practice.

More recently Shephard et al. [15] have questioned the usefulness of the terms "competence" and "capability", highlighted the failure of existing competence frameworks to distinguish between the outcomes that a learner is expected to achieve and the motivation that a learner may have (or not) to actually enact them. These authors note the internal contradiction between promoting sustainable development competences that ostensibly promote values such as democracy and self-regulation while expecting learners to be wanting to achieve a range of predetermined outcomes. They do concede, however, that competences that apply to professional roles, which individuals have chosen, can legitimately demand obligatory outcome both in terms of skilled behaviors and the willingness to perform them.

\subsection{Towards ESD Competences}

In 1997 the Organisation for Economic Cooperation and Development (OECD) launched the Defining and Selecting Key Competences Project (DeSeCo). This provided a conceptual framework for defining and evaluating competences for what was then termed "a successful life and a well-functioning society" [16]. Such competences were to extend beyond knowledge and skills to include the ability to meet complex demands, drawing on psychosocial resources such as skills and attitudes in particular contexts [17].

Meanwhile, at the 2003 "Environment for Europe" conference in Kiev, Ministers of the Environment from the 55 Member States of the United Nations Economic Commission for Europe (UNECE) called for ESD to be included in curricula across all phases of education. Responding to this call and building on the work of DeSECo, the Environment and School Initiatives (ENSI) developed the CSAT model-Curriculum Sustainable Development, Competences, Teacher Education [13]. CSAT has three components. Firstly, it defines five learning processes for sustainable development: knowledge; systemic thinking; emotions; ethics and values; action. Secondly, the model perceives the teacher's professional dimensions as an individual, as a member of the school and as a member of the community. The third component comprises the three interconnected "overall competences" of teaching, reflecting, and networking with others. All three components are understood to move and overlap in various ways as the teacher responds to the complexity of ESD. The sophistication of this model is impressive but also perhaps its major drawback as it is difficult to grasp its potential without a lengthy explanation of its structure even before unpacking each component.

While the ENSI model was being elaborated, UNECE was drafting a Strategy for ESD together with indicators to monitor its implementation [18]. At the first monitoring meeting for the ESD Strategy in Belgrade in 2007, UNECE Member States reported that the lack of competence among teachers and other educators was the most significant "bottleneck" facing the promotion of ESD in their countries. UNECE established an expert group with the mandate to prepare a range of core competences in ESD for educators plus guidelines for developing the competences among educators; this was intended to serve as a tool for facilitating the integration of ESD into all educational programs at all levels. The expert group identified 39 competences presented in a $4 \times 3$ matrix (Table 1) with the rows aligned to UNESCO's four pillars of learning: learning to know; learning to do; learning to live and work together; learning to be [19]. The columns represented three broad domains: holistic approach; envisioning change; achieving transformation [20]. 
Table 1. The UNECE Competences for educators in education for sustainable development. (Source: [20]).

\begin{tabular}{|c|c|c|c|}
\hline & $\begin{array}{c}\text { HOLISTIC APPROACH Integrative } \\
\text { Thinking and Practice }\end{array}$ & $\begin{array}{c}\text { ENVISIONING CHANGE Past, Present, } \\
\text { and Future }\end{array}$ & $\begin{array}{c}\text { ACHIEVING TRANSFORMATION People, } \\
\text { Pedagogy, and Education Systems }\end{array}$ \\
\hline $\begin{array}{l}\text { Learning to know } \\
\text { The educator understands.... }\end{array}$ & $\begin{array}{l}\text { - } \quad \text { the basics of systems thinking } \\
\text { ways in which natural, social, and } \\
\text { economic systems function and how } \\
\text { they may be interrelated } \\
\text { the interdependent nature of } \\
\text { relationships within the present } \\
\text { generation and between generations, as } \\
\text { well as those between rich and poor } \\
\text { and between humans and nature } \\
\text { their personal world view and cultural } \\
\text { assumptions and seek to understand } \\
\text { those of others } \\
\text { the connection between sustainable } \\
\text { futures and the way we think, live } \\
\text { and work } \\
\text { their own thinking and action in } \\
\text { relation to sustainable development }\end{array}$ & $\begin{array}{l}\text { - } \quad \text { the root causes of } \\
\text { unsustainable development } \\
\text { that sustainable development is an } \\
\text { evolving concept } \\
\text { the urgent need for change from } \\
\text { unsustainable practices towards advancing } \\
\text { quality of life, equity, solidarity, and } \\
\text { environmental sustainability } \\
\text { the importance of problem setting, critical } \\
\text { reflection, visioning and creative thinking } \\
\text { in planning the future and effecting change } \\
\text { the importance of preparedness for the } \\
\text { unforeseen and a precautionary approach } \\
\text { the importance of scientific evidence in } \\
\text { supporting sustainable development }\end{array}$ & $\begin{array}{l}\text { - why there is a need to transform the } \\
\text { education systems that } \\
\text { support learning } \\
\text { why there is a need to transform the } \\
\text { way we educate/learn } \\
\text { - why it is important to prepare learners } \\
\text { to meet new challenges } \\
\text { the importance of building on the } \\
\text { experience of learners as a basis } \\
\text { for transformation } \\
\text { how engagement in real-world issues } \\
\text { enhances learning outcomes and helps } \\
\text { learners to make a difference in practice }\end{array}$ \\
\hline $\begin{array}{l}\text { Learning to do } \\
\text { The educator is able to .... }\end{array}$ & $\begin{array}{l}\text { - } \quad \text { create opportunities for sharing ideas } \\
\text { and experiences from different } \\
\text { disciplines/places/cultures/generations } \\
\text { without prejudice and preconceptions } \\
\text { work with different perspectives on } \\
\text { dilemmas, issues, tensions, } \\
\text { and conflicts } \\
\text { connect the learner to their local and } \\
\text { global spheres of influence }\end{array}$ & $\begin{array}{l}\text { - critically assess processes of change in } \\
\text { society and envision sustainable futures } \\
\text { communicate a sense of urgency for } \\
\text { change and inspire hope } \\
\text { facilitate the evaluation of potential } \\
\text { consequences of different decisions } \\
\text { and actions } \\
\text { - use the natural, social, and built } \\
\text { environment, including their own } \\
\text { institution, as a context and source } \\
\text { of learning }\end{array}$ & $\begin{array}{l}\text { - facilitate participatory and } \\
\text { learner-centered education that } \\
\text { develops critical thinking and } \\
\text { active citizenship } \\
\text { assess learning outcomes in terms of } \\
\text { changes and achievements in relation } \\
\text { to sustainable development }\end{array}$ \\
\hline
\end{tabular}


Table 1. Cont

\begin{tabular}{|c|c|c|c|}
\hline & $\begin{array}{c}\text { HOLISTIC APPROACH Integrative } \\
\text { Thinking and Practice }\end{array}$ & $\begin{array}{c}\text { ENVISIONING CHANGE Past, Present, } \\
\text { and Future }\end{array}$ & $\begin{array}{c}\text { ACHIEVING TRANSFORMATION People, } \\
\text { Pedagogy, and Education Systems }\end{array}$ \\
\hline $\begin{array}{l}\text { Learning to live together } \\
\text { The educator works with others } \\
\text { in ways that.... }\end{array}$ & $\begin{array}{l}\text { - } \quad \text { actively engage different groups across } \\
\text { generations, cultures, places, } \\
\text { and disciplines }\end{array}$ & $\begin{array}{l}\text { - } \quad \text { facilitate the emergence of new worldviews } \\
\text { that address sustainable development } \\
\text { encourage negotiation of } \\
\text { alternative futures }\end{array}$ & $\begin{array}{l}\text { - challenge unsustainable practices } \\
\text { across educational systems, including } \\
\text { at the institutional level } \\
\text { help learners clarify their own and } \\
\text { others' worldviews through dialogue, } \\
\text { and recognize that alternative } \\
\text { frameworks exist }\end{array}$ \\
\hline
\end{tabular}

\section{Learning to be}

The educator is someone who

....
- $\quad$ is inclusive of different disciplines, cultures and perspectives, including indigenous knowledge and worldviews
- is motivated to make a positive contribution to other people and their social and natural environment, locally and globally

- $\quad$ is willing to take considered action even in situations of uncertainty
- $\quad$ is willing to challenge assumptions underlying unsustainable practice

- is a facilitator and participant in the learning process

- $\quad$ is a critically reflective practitioner

- inspires creativity and innovation

- $\quad$ engages with learners in ways that build positive relationships 
The UNECE framework represents a significant attempt to identify competences in a systematic and comprehensive manner with the explicit aim of becoming a commonly shared reference framework. Beyond identifying these competences, the expert group presented a tool for practical workshops for policymakers and ESD practitioners. The aim here was to explore how educator competences could be developed, emphasizing that learning about the ESD competences should not be an end in its own right but should be seen as "part of a process through which policy and practices are changed" [21] (p. 7). Despite these efforts, the UNECE ESD competence framework does not appear to have had the impact that was sought, largely because it remains a theoretical tool. The 39 competence statements are not expressed as assessable competences neither have they been tested against real educational contexts. Among partners involved in the RSP project, most of whom had attempted to implement the UNECE framework in some form, there was a general consensus that the UNECE competences were abstract, complex, and repetitious, and that the total of 39 was simply unmanageable.

Since publication of the UNECE framework, the concept of competences in relation to ESD has continued to develop. Indeed, competence acquisition is deemed to be as necessary as ever because it shifts education from input to output orientation $[22,23]$ and consequently bridges the gap between knowledge and action [24]. Despite the progress and developments in this area, the literature remains dominated by "laundry lists" [25] and a lack of justification linking theoretical frameworks with their practical implementation. Subsequent efforts to address this gap include the work of Lozano et al. [26,27], who have sought to link pedagogical approaches to sustainable development competences, while Bürgener and Barth [28] have explored the potential of open learning environments [29] in supporting sustainability competences among educators. With this in mind, the RSP project set out to revisit the UNECE competence framework with the explicit aim of developing an accessible set of competences that can be used in accreditation models across a range of jurisdictions.

\section{Materials and Methods}

\subsection{The RSP Distillation Process}

RSP partners reduced UNECE's original 39 competence statements down to 12 through a process of "distillation". Each partner took a slightly different approach but at its core the process involved a careful reading of the UNECE framework and matching statements that appeared to cover similar learning outcomes and reformulating them so that statements could be combined and that some form of assessment would be feasible. Gaps were also identified as the UNECE competences were compared with other sustainable development and ESD competences frameworks [30,31]. Even at this early stage, the opinions of teachers and experts were sought within the partner countries, often through several cycles.

After six months, an initial draft set of reformulated competence statements was agreed at a project meeting hosted by Frederick University in Cyprus. At this time several competence templates were shared and discussed in a session hosted by a colleague with expertise in accreditation. It became apparent at this point that if the RSP framework was formulated to fit a given competence template for one jurisdiction, this would make it less accessible to others. This is because each country, and in some cases each region within a country, uses its own template. An effort was made to retain the structure of the three columns used in the original UNECE framework, but it was decided to drop the use of UNESCO's four pillars of learning (learning to know, learning to do, etc.) as used by UNECE. This is because any competence would necessarily include all these learning attributes. It was eventually agreed that each RSP competence would comprise the following: title; brief descriptor; three verifiable learning outcomes; enough additional details (termed "underpinning components") as deemed necessary to make the competence understandable to a non-expert audience.

After the Cyprus meeting the distillation exercise continued in partner countries and included a wide range of actors. In Italy, for example, the process involved members of the Italian Association for Sustainability Science (IASS), chiefly experts and scholars from non-education focused university 
departments. This generated a broader perspective on the RSP concepts and the elements that emerged from this consultation were seen as necessary from a sustainability science perspective. These concepts include interdependencies in space and time; transdisciplinarity, i.e., going beyond disciplines to integrate knowledge from science and society [32]; an evolutionary view of natural and social processes, understanding of the difference between deterministic or predictive laws and constraints within which a variety of processes are always possible [33]. Respondents also highlighted the need for diversity in the form of a plurality of cultural views and values along with the diversity of species and called for an awareness of limits, not only planetary limits but also time limits in relation to biological cycles and human possibilities. A consideration of complex natural and social systems emphasized the need for an awareness of the unpredictability of-and the risk associated with-our every action or inaction. Such concepts were seen as insufficiently stressed by the UNECE competences and consequently were included in the RSP framework.

\subsection{Delphi Studies: Testing the Competences}

The distillation process moved seamlessly into a phase of testing and developing the RSP framework. This was achieved by partners running carefully monitored training programs (see below) while in three countries partners used a Delphi research procedure. Delphi is "a method for structuring a group communication process so that the process is effective in allowing a group of individuals, as a whole, to deal with a complex problem" [34]. Each RSP partner invited individual contributions that were shared among participants to evaluate the results and formulate next steps. This procedure was repeated in cycles until the diverse results lead to an acceptable level of consensus.

\subsubsection{Hungary}

The Hungarian Research Teachers' Association conducted a three-cycle Delphi research involving ESD educators who were active in informal and non-formal education settings including members of non-governmental organizations and forest school educators. These educators reach about $20 \%$ of the primary and secondary school student population in Hungary and collaborate regularly with teachers from about $30 \%$ of schools.

In the first step, using a 4-point Likert scale, practitioners reflected on the relevance of the 12 competence areas. This was the most diverse group including 42 educators from 30 different organizations. In the second cycle, 17 practitioners reflected in the same way on learning outcomes and competence elements with the possibility to add comments. In the third cycle, an expert group of six experienced educators reflected on the findings of the earlier cycles via video conference.

Besides sketching a positive view on the relevance of the competence framework in general, this research drew attention to interrelationships and the overlapping of competences in the model. The research also emphasized areas where more intense training might be needed in Hungary. Some competences, such as empathy, innovation and critical thinking were problematic to translate accurately in the educational framework and proved difficult to demonstrate in practice. These findings correspond with national [35] and international data [36]. The bottleneck of acting for sustainability appears not to be factual knowledge but the integration of this knowledge with the practical experience of students. The research also underlined an interesting phenomenon: educators interpreted many of the competence areas as primarily competences that students (but not educators) need to possess. Furthermore, assessment of competences (especially in the case of empathy) raised concerns in the second and third cycles. These findings were of immediate value in tailoring local educator training programs to participants' needs.

\subsubsection{The Netherlands}

The first Delphi cycle conducted by Dutch partner Duurzame PABO discussed the concept of the 12 competences with a range of experts including lecturers, managers, and coordinators of education programs. Several sessions with different experts raised the issues of comprehensibility and applicability. 
For some the content proved to be too complicated to be readily understood and a recommendation was made to produce a simplified version [37]. The content overall was widely approved and at one point the UNESCO Chair for Re-orienting Teacher Education for Sustainability, Charles Hopkins, stated that the RSP competences have added value to teacher training institutes (TEIs) by supporting the "hidden curriculum" for sustainability.

In a second cycle, the draft RSP competences were used with final year TEI students. After presentations and discussion, students worked on activities to improve specific competences by themselves with the support of their peers. Results from these sessions were discussed among the project team, which led to the clarification of text and some simplification. This also highlighted the important notion that schools differ in their interpretation of texts.

The competences were originally drafted in English, so they had to be translated into Dutch, a process that generated subtle differences in interpretation and meaning. This was unavoidable and was considered acceptable provided that the result reflected the spirit of the original text and that the competences remained usable. The Dutch partner had taken the initiative to develop the RSP website and so the team was forced to triple check all texts and consider the correctness of translations with many experts. An important outcome of this effort is the fact that the competences are being used in several Dutch TEIs and are currently informing the development teams who are renewing the Dutch curricula for primary and secondary education.

\subsubsection{Italy}

The Italian Delphi study involved a panel of experts drawn from both inside and outside IASS. Nineteen participants (equally distributed across South and North of Italy) included local government representatives with responsibility for environmental education and defining professional qualifications, researchers and scholars on environmental and sustainability education, practitioners (environmental educators and experts from the main environmental non-governmental organizations (NGOs) such as Legambiente) and researchers on sustainability issues. Participants were invited to explore the draft RSP competences and learning outcomes and to relate these to their own practice/experience.

Results of a questionnaire sent to the group raised the following issues:

- the need for coherence in relation to the theory and practice of sustainable education

- $\quad$ the practicality of the framework for assessing and possibly certifying the competences

- $\quad$ the practicality of the framework for training courses for ESD teachers and educators

- efficacy of the framework in terms of its completeness and its clarity (with some missing and repeated elements being identified).

These results were shared among project partners at a meeting in Hungary where they either contributed to the validation of RSP framework or led to adjustments in text and structure. It was at this meeting that the final structure of the framework was agreed. This comprised 12 competences arranged in a $4 \times 3$ matrix (in line with the UNECE structure) with each competence having a short descriptive statement behind which would be three assessable learning outcomes. Below this would be further "underpinning components" that would help to explain further the concepts behind each competence.

\subsection{Competences for Learners or Educators: The Dual Purpose}

During the meeting in Hungary partners noted that each competence statement had a dual purpose, i.e., describing both the competence of the educator and the competences to be developed within the learners with whom they worked. To clarify this relationship, it was felt that the high-level competence statement should apply unambiguously to the educator while the learning outcomes would reflect attributes that the educator would help learners to acquire. The underpinning components were framed as attributes that educators would need to fully achieve the requirements 
of each competence. It was also agreed that every effort should be made to avoid confusion between competences for ESD and generic sustainable development competences e.g. [23,30].

\subsection{Partner Survey}

At this stage in the project, the internal and external evaluator conducted a joint survey among the project partners to explore the qualification systems in partners' countries and ascertain why a teacher or educator in each country would aim for an ESD qualification. Responses suggest that the main beneficiaries of this work would be motivated teachers in formal education with another significant group being professionals involved in informal and non-formal education and employed in institutions dealing with ESD. For this group it was emphasized that certification should give credit to prior learning and experience possibly through the production of a portfolio. A third group identified as people with an interest in certification were students in vocational schools wishing to pursue a career in EE/ESD. In this way the survey validated some of the assumptions made in the project proposal and highlighted the need to make qualifications available at pre-service and professional levels while maintaining "flexibility and adaptation to the countries" needs" [38].

Adjustments to the framework itself continued throughout the project, particularly in light of the educator preparation programs (see below) and the "multiplier events" (public meetings) held by each partner in the final stages of the project. The foregoing discussion has outlined the process through which the RSP competence framework was developed; the following section provides a review of the framework itself. This, together with the website, which provides guidelines for educator preparation programs, represents the principal legacy of the project.

\section{Results}

\subsection{The RSP Competence Framework}

The resulting framework can be presented in a matrix of 12 competences [39,40] arranged in the same three columns as the UNECE framework under headings that reflect essential ESD characteristics: holistic approach, envisioning change, and achieving transformation. The four rows of the RSP competence table suggest a process that the educator might follow:

(a) integration-using knowledge from different dimensions, looking at interconnections and cause-effect relationships

(b) involvement-building this understanding into their personal sense of commitment

(c) practice-combining the two stages above in their practical work as an educator

(d) reflection-evaluating the process and results of their work, assuming responsibility, and taking decisions before repeating the process in an iterative learning loop.

During the testing phase, partners noted how the competences could not be isolated in the manner suggested by this table format. The Hungarian research had suggested that competences could be re-combined in novel ways. Similarly, a Dutch teacher attending an RSP training program observed:

"As soon as you start to teach one of the competences, you inevitably touch on the other 11." (Teacher in The Netherlands)

With this in mind, partners experimented with alternative designs such as representing the competences as segments of concentric circles although this proved equally problematic as they were still seen as discrete entities. It was also noted that the reflective cycle suggested by the rows in the RSP matrix should apply to all competences so while it would be important to highlight this habit of mind, it should not be restricted to any specific cluster of competences. Ultimately, the idea of an artist's palette was suggested as a means of demonstrating the fluid and flexible nature of competences while suggesting that they might be combined by the educator in creative ways depending on the demands of the context (Figure 1). 


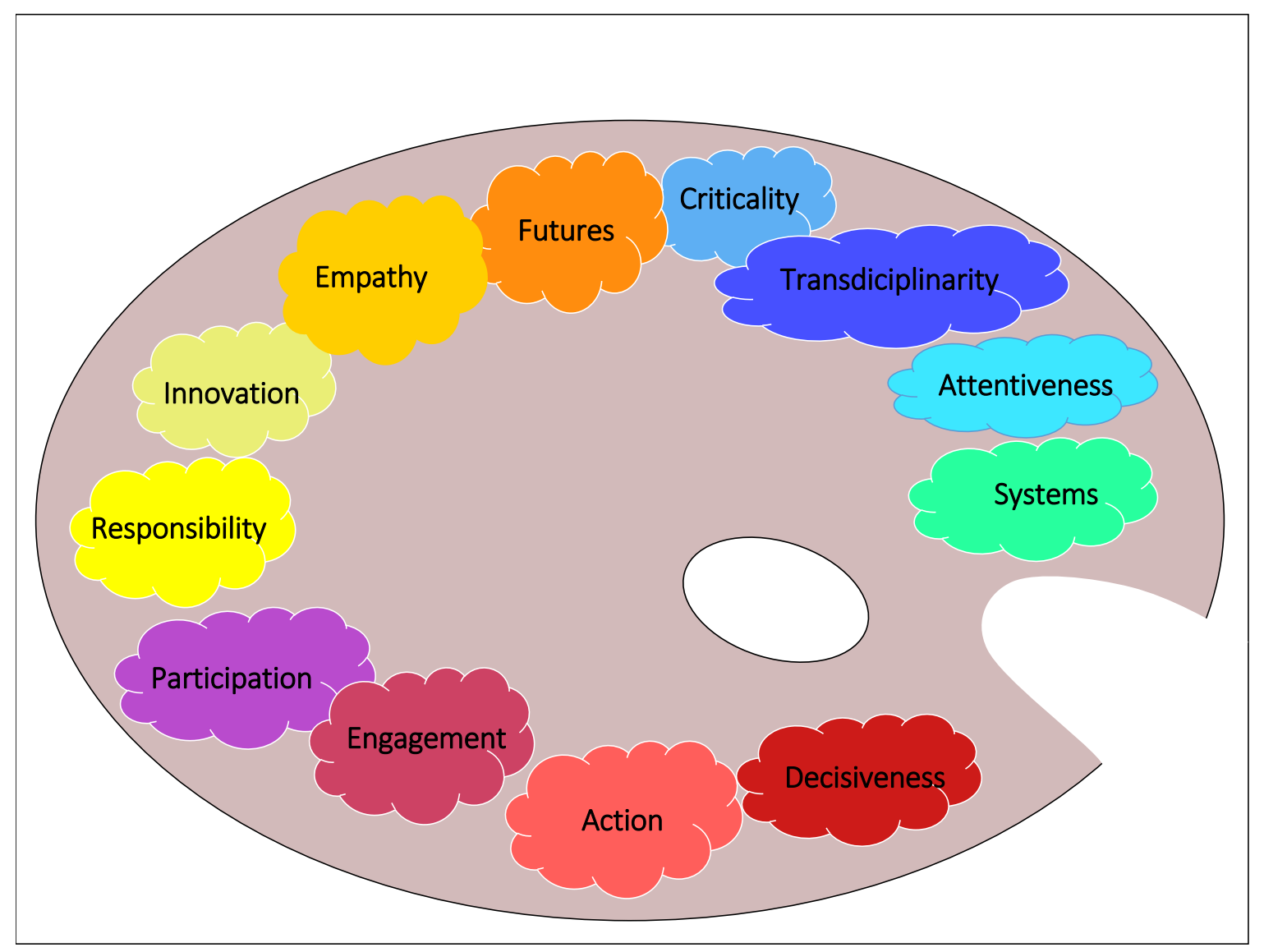

Figure 1. The RSP Palette.

\subsection{The Competences}

As discussed above, the RSP competences evolved through a process of close reading of the UNECE competence framework, a review of related literature and an exhaustive process of professional engagement through Delphi research cycles, workshops, and training programs. The 12 competences to emerge from this process are introduced below, each with a brief rationale.

\section{- Systems}

Basic knowledge about systems is required if one is to understand global challenges such as climate change. Dealing with complex "wicked problems" [41] requires a critical understanding of the relationship between environmental and social systems and the ability to see connections between components and patterns across temporal and spatial domains [42]. This also requires us to recognize how problems are embedded with values, needs and motives, that uncertainty cannot be eliminated and that there may be implications for our actions which are not foreseen [43].

\section{- $\quad$ Futures}

Futures thinking offers ways of addressing and helping to shape the future. It allows for informed reflection on the challenges we face and on how our different actions can contribute to desirable or undesirable futures. It enables individuals to recognize relations and possible evolutions between past, present, and future and envision possible or thinkable futures alternatives and their impact. Being able to envision a sustainable future creatively and innovatively is the first step towards achieving it [44]. 


\section{- Participation}

Participation in decision making is an essential characteristic of sustainable development governance. It is, therefore, essential that citizens can actively engage in different ways, share and discuss their ideas and be able to contribute towards societal transformations for sustainable development in collective efforts [45].

\section{- Attentiveness}

This competence relates to knowledge about sustainability issues while emphasizing the difference between information and understanding. Our pre-existing knowledge determines how we see the world and what we notice in our environment [46]. Therefore, simply seeing, hearing, or even discussing new information, without becoming explicitly cognizant of it, may not help in understanding the relationships and principles that underlie situations, especially in the case of seemingly contradictory information [47]. The goal of an educator is to help learners to process new knowledge explicitly and not to simply be exposed to information about the world.

\section{- Empathy}

Understanding and responding effectively to our own and others' emotions helps educators to create positive learning environments, build connections, and develop sources of resilience in the face of inevitable social change. Emotions such as hope, for example, have multiple dimensions; blind hope could be a form of denial, whereas hope founded on evidence [48] can help us act constructively on the fears and anxieties that issues around (un)sustainability can arouse.

\section{- Engagement}

Educators need to satisfy the need for relatedness and autonomy of learners if they are to become motivated to learn about complex systems, to value personal growth and community development and to strive to live more sustainable lives. This means ensuring that learners feel that their ideas, emotions, values, and pace of development are respected. This builds on self-determination theory, an idea that has been validated empirically many times $[49,50]$.

\section{- Transdisciplinarity}

Working towards sustainability calls for the ability to collaborate with a diverse group of people. This goes beyond multidisciplinary teams to consider non-disciplinary actors such as members of a local community. Educators are challenged to promote this competence among their learners and model it by, for example, facilitating school-community collaborations. Another dimension of transdisciplinarity is collaboration within an educational setting through a "whole-institutional approach" [18] (p. 102), which is widely seen as the most effective means of promoting ESD.

\section{- Innovation}

A major challenge for those educating in the context of real-world issues is that traditional didactic methods are rarely the most appropriate; approaches such as situated learning and living laboratories are gaining in popularity. Educators will need to reflect on their practice and renew their methods as they adapt to new situations while understanding that "new" is not necessarily better.

\section{- Action}

Helping learners understand that they can make a difference is a critical role for any ESD educator. Tried and tested methods such as the action competence approach [51] can provide opportunities for learners to express their "political existence"-interacting with strangers as they find their place in the world [52]. 


\section{- Criticality}

It could be said that a failure to think critically lies behind many of our current "wicked problems" and in an era of "fake news" it is more important than ever to evaluate information, data, actions, and their possible consequences. Educators therefore need to be confident in helping learners to explore underlying assumptions, keeping in mind their own and others' values. This includes capacities to "construct" (and not only analyze) a problem, to evaluate the reliability of information sources, to draw inferences and deductions and to control and monitor reasoning [53].

\section{- Responsibility}

The educator of ESD may be in the fortunate position of recognizing that they are carrying out meaningful work and thus contributing to a meaningful life. As well as acting transparently and responsibly themselves, the educator of ESD will have a range of tools, e.g., role play, simulations, real-world engagements, through which to develop their learners' abilities to act responsibly. In this way, they will encourage long-term thinking about what kind of human beings we want to be and what kind of world we want to live in [54].

\section{- Decisiveness}

Developing a society that lives in balance with the environment and that is sustainable means that changes to our individual and collective behaviors need to be made. This requires educators to expose their learners to ethical dilemmas and leading them to think deeply about them. Ultimately, any change requires decisions to be made regarding its nature coupled with an ability to act decisively yet cautiously, weighing up available evidence and recognizing the complexity of the issue [55].

\subsection{Levels of Achievement}

Defining competences that are to be observed at a given assessment point, particularly in relation to an activity as complex as teaching is not as straightforward as some accreditation frameworks might suggest. Acquiring competence is not a sudden process, neither is it one with a definitive end point; competences may be enhanced with practice throughout one's life. With this in mind, an effort was made by RSP partners to define levels of competence acquisition. Close attention was paid to the RESFIA $+\mathrm{D}$ model [30] that defines seven levels of competence. The distinctions in this case were considered to be too fine grained to be practical and it was agreed that three levels of competence would suffice. These are defined as:

Level 1-The educator uses the competence effectively and experiments with care in familiar contexts

Level 2-The educator reflects on the competence and can use it in new contexts, to face new challenges, and adapt or invent new tools to better exercise the competence

Level 3-The educator has mastery of the competence while simultaneously understanding that it is necessary to continue to improve it; they promote the competence among collaborators and can guide a shared path of training, innovation, and critical reflection on the competence and good practices associated with it.

\subsection{Educator Preparation Programmes}

As soon as a workable draft of the competence framework became available, project partners began testing all aspects of the framework through the facilitation of workshops and training programs involving a wide range of educators, school leaders and / or student teachers in each country across a variety of ISCED levels (ISCED = UNECO's International Standard Classification of Education). The aim was to engage 400 participants across the partnership; the final total exceeded 500 (Table 2). 
Table 2. Summary of RSP training programs.

\begin{tabular}{ccccc}
\hline Partner & $\begin{array}{c}\text { No. of } \\
\text { Participants }\end{array}$ & Nature of Participants & ISCED Level & $\begin{array}{c}\text { Timing of } \\
\text { Program }\end{array}$ \\
\hline $\begin{array}{c}\text { Frederick University, } \\
\text { Cyprus }\end{array}$ & 33 & $\begin{array}{c}\text { Experienced teachers } \\
\text { and ESD professionals }\end{array}$ & 6 & $\begin{array}{c}\text { Series of } 2 \mathrm{~h} \\
\text { workshops }\end{array}$ \\
\hline $\begin{array}{c}\text { Hungarian Research } \\
\text { Teachers' Association }\end{array}$ & 80 & In-service teachers & N/A & $\begin{array}{c}\text { 30 h of webinars } \\
\text { and face-to-face }\end{array}$ \\
\hline $\begin{array}{c}\text { Italian Association for } \\
\text { Sustainability Science }\end{array}$ & 36 & $\begin{array}{c}\text { In-service teachers, } \\
\text { Science of Education } \\
\text { students }\end{array}$ & 6 & $\begin{array}{c}\text { One 40-h and one } \\
\text { 18-h program }\end{array}$ \\
\hline $\begin{array}{c}\text { University } \\
\text { lecturers/teacher } \\
\text { Netherlands }\end{array}$ & 146 & $\begin{array}{c}\text { trainers, head teachers, } \\
\text { student teachers, NGO } \\
\text { staff }\end{array}$ & $5 / 6$ & $5 \times 2$-h \\
\hline $\begin{array}{c}\text { Tallinn University, } \\
\text { Estonia }\end{array}$ & 149 & $\begin{array}{c}\text { Bachelors students and } \\
\text { in-service teachers }\end{array}$ & 6 & Eight-week course \\
\hline $\begin{array}{c}\text { University of } \\
\text { Gloucestershire, UK }\end{array}$ & 80 & Student teachers & 5 & 24-h over 12 weeks \\
\hline
\end{tabular}

Feedback from these programs was shared by partners and informed periodic reviews of the framework as well as the project evaluation report. Many of the activities that were developed and trialed during this process were subsequently written up and are freely accessible via a purpose-built website: www.aroundersenseofpurpose.eu

The range of pedagogic activities can be illustrated by two examples on the theme of "systems thinking":

\section{Example 1: The Webbing Game}

In the UK, student educators were introduced to this activity whereby each student is assigned a woodland organism (worm, caterpillar, fox, oak tree, wood mouse, toadstool, etc.) and then uses lengths of string to link to plants or animals that their organism eats or creatures that eat them. The leader takes care to ensure that all students are connected to the emerging "web" and that the student assigned as "oak tree" is connected multiple times. The leader then enacts the felling of the oak tree; the student tree sits down while holding tightly to the strings in their hand. As each student in turn feels that a string in their hands is being pulled, they also sit down holding tightly to their strings as they do so. Within a few seconds the entire class has been brought down to the floor thus providing a crude but effective analogy for the way in which nature is interconnected. The discussion that follows can be adjusted according to the level of the students; in this case, the level 5 student teachers could see immediately how they might adapt the activity to their own teaching practice and suggested activities that they could use to extend the learning with young children.

\section{Example 2: An Ecological Field Visit}

A different approach was taken in Estonia where first year (Level 4) special pedagogy students were given an eight-week course in "ecological pedagogy" during which, students discussed ecological principles within lectures. Two thirds of the way through the course the students were invited to choose a natural area (forest, meadow, bog, coast, river, etc.) and physically go there with the aim of identifying these ecological principles in the real world, e.g., positive/negative feedback mechanisms, ecological levels, cycles, ecological amplitude, relationships, succession, population dynamics). Students then posted their analytical notes 
and photographs to a shared learning environment (eDidaktikum). In a final meeting, students presented their insights, first in small groups and then as groups to the whole class. In this example, about $25 \%$ of students expressed that suddenly they realized that the "separate" ecosystem principles they had discussed actually form a coherent, systemic whole. What these students previously saw as simply a natural area, they now understood in terms of scientific concepts while also noticing small elements in nature that they had previously overlooked. This led to new questions with some drawing incorrect conclusions based on primitive extrapolations, which is a natural part of conceptual development. Following this experience, the task was repeated giving those students who had not had such insights a chance to discover them for themselves while the others looked for yet more examples of interconnections in nature. In an exam that followed the students had a chance to discuss individually how their thinking about these systematic phenomena has changed. As well as enhancing their metacognitive awareness of systems thinking, these students, perhaps more implicitly, addressed the competences of empathy, attentiveness, responsibility, criticality, and action.

In different ways both of these examples illustrate an effort to connect theoretical discussion with practical activity, to give students ample opportunity to discuss their emerging understanding and to learn from each other as well as their teachers.

\subsection{Assessing the Competences}

Notwithstanding the RSP partners' agreement on the three levels of competence achievement described above, the issue of assessment could not be resolved during this project and is consequently a focus for the second phase of the project (RSP II 2019-2021). That said, several approaches have been piloted under RSP I. For example, students conducting the ecological pedagogy work described above were assessed using existing tools such as the New Ecological Paradigm or NEP scale [56] plus some open-ended questions to assess students' perspectives and level of conceptual thinking. Results provided useful indications but were described by the team as being too intuitive to be dependable.

The evaluation process in Italy was based on a portfolio of evidence produced by the participating teachers and environmental education specialists. This went beyond the content of the training courses to include situations in the participants' personal and professional lives thereby maximizing their opportunities to demonstrate ownership of specific RSP competences. The reflections in the portfolios give clues as to which competences align closely with the participants' own feelings, and are therefore easily applied in their professional lives, and which are more difficult for them to engage with or apply. The evaluation process used the three levels of achievement described above and asked participants to compare their self-evaluation with peer evaluation (based on the reading of portfolio) with the results recorded on a spider web diagram (Figure 2). The reflective discussions that followed this exercise proved valuable in revealing both difficulties and advantages of the RSP framework while taking into account not just the training course but the professional experience of participants. To date, initial results, particularly themes to emerge from discussions with participants, have simply informed internal project discussions. It is expected that a systematic analysis of further assessments will be published as an output of the second phase of the project. 


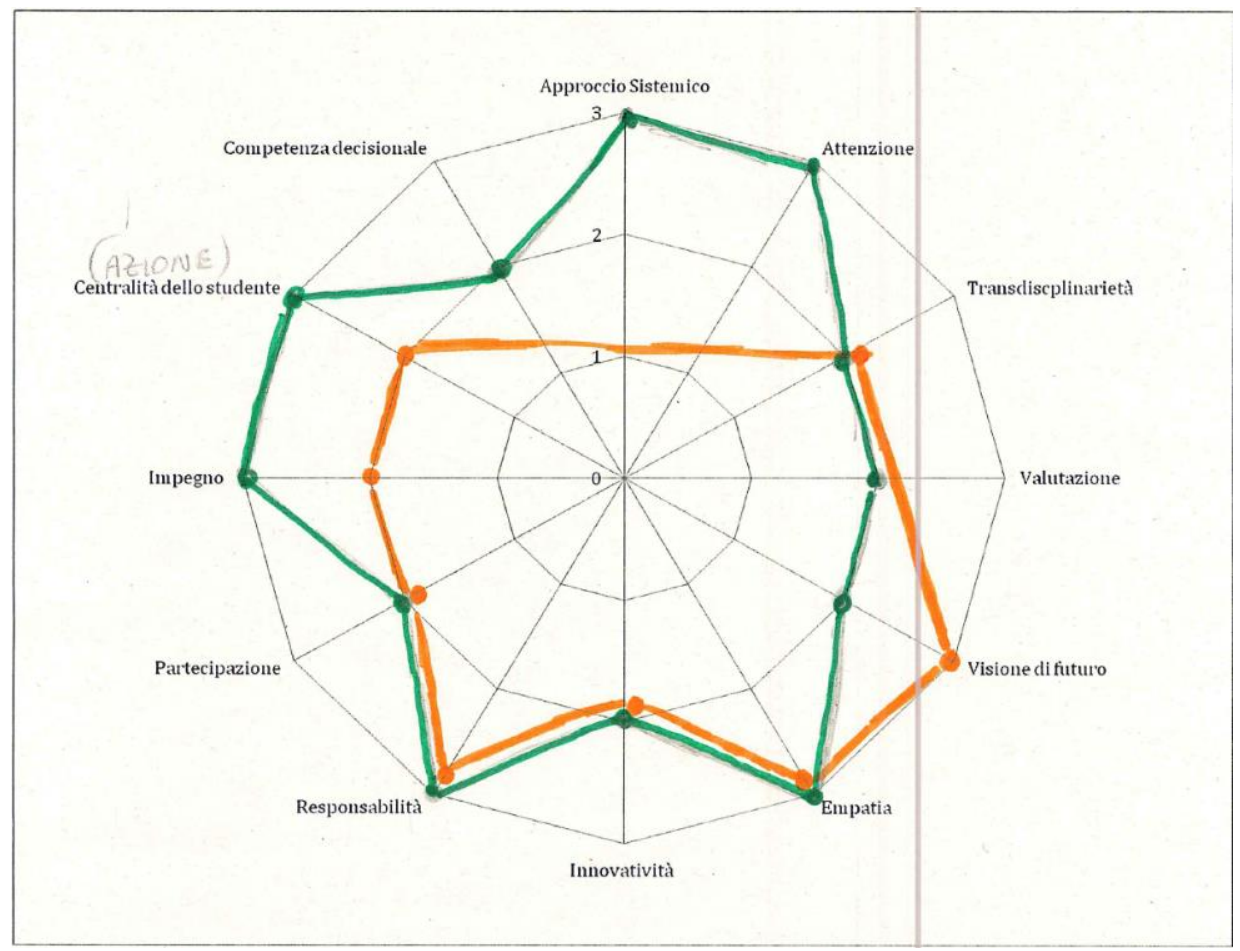

Figure 2. Example of spider diagram used in self-evaluation and pair evaluation (Italy).

In the UK, the team explored the impact of engagement with the RSP competences framework on pre-service teachers using the concept of vertical and horizontal learning [57]. This involved students presenting to the breadth of their learning (horizontal) and the depth of their understanding (vertical). Initial results [39] suggest that while there may be some value to this approach, time is required for students to fully grasp the vertical-horizontal distinction.

\subsection{The Project Evaluation Process}

Monitoring and evaluation is essentially a project management issue; however, in the case of RSP, external evaluation played a central role in the development of the competence framework. The evaluation plan [38] identified three functions: monitoring, internal evaluation, and external evaluation. The latter process was perceived as a series of participative action learning and reflection cycles running throughout the project with the external evaluator acting as a "critical friend", i.e., "a trusted person who asks provocative questions, provides data to be examined through another lens, and offers critique of a person's work as a friend" [58] (p. 50).

The external evaluator developed quality criteria with partners at the start of the project and tracked progress through emails, virtual meetings, and attendance at some transnational meetings. Criteria included, among other things, consistency in shared values across processes and products, the quality and usefulness of products in different contexts and the connection between theory and practice. While collecting evidence of quality, the evaluator paid particular attention to any emerging patterns or unforeseen events. In this way, the external evaluation provided a triangulation or cross-checking function for the project, offering critiques that helped partners to reflect systematically on data that had been collected from different sources and through different methods. Such an approach proved critical in helping partners to identify and overcome bias in their thinking. The final evaluation report [59] cites one partner who describes the project as, " . . a learning process that is giving us opportunities to reconsider our frame of mind ..." This openness to change and collaboration would inevitably contribute to the quality of the project outputs. 
The final report also stressed the impact that the project had in some of the countries involved and on the partner institutions themselves. In Hungary for example, a new national framework for teachers' continuing professional development includes a strand on sustainable development which incorporates the RSP framework; meanwhile in Italy, the lead institution IASS, found that the project helped to forge closer ties with significant actors such as the Italian UNESCO Commission.

\section{Discussion}

Through our involvement in the first phase of RSP, the thinking and practice of all partners has developed markedly. This is reflected in the project outputs and recommendations that can be summarized under four broad categories: the identification of competences; pedagogical approaches; assessment; accreditation models. Each of these will be discussed in turn.

\subsection{The Identification of Competences}

Educational outcomes, particularly within formal education, tend to emphasize the acquisition and development of knowledge. Given that a principal focus of ESD is to enable individuals to take informed action, it is clear that knowledge alone is insufficient hence a focus on competences seems appropriate. The term "competence" is broader than "skills" and incorporates "an interplay of knowledge, capacities and skills, motives and affective dispositions" [60] (p. 129). Care was taken to review existing ESD and sustainable development competence frameworks before deciding to elaborate another version. The experience of project partners in attempting to work with these frameworks, particularly that of UNECE, informed this decision.

Although an extensive program of structured consultations led eventually to the 12 RSP competences, no framework is definitive and the RSP model remains open to review and modification. Piloting of the RSP framework confirmed a shared understanding that no competence can be seen in isolation and this called into question the presentation of the competences in a grid format. An early attempt to avoid such a rigid, linear approach involved representing the competences as segments of concentric circles although this proved equally problematic. A further representation of the competences as colors on an artist's palette is proposed because this highlights the fluid and flexible nature of the competences and suggests that they have the potential to bleed into one another or be mixed together as context demands.

\subsection{Pedagogical Approaches}

At its core ESD is relational [61] and represents a process of social learning [62]. It was therefore clear that an appropriate pedagogical approach should encourage dialogue and the sharing of thoughts and ideas. The role of the teacher in these activities is unquestionably that of facilitator as participants are led into explorations of values, beliefs, and visions of alternative futures. The pedagogy of the RSP activities is underpinned by principles of collaborative and socio-constructivist theories of learning $[63,64]$ in which participants are encouraged to take an active role. Activities include simulation, role play, debate, and problem solving. Above all there is an attempt to provide authentic, real-world tasks to make activities meaningful and to build confidence. This approach resonates with the concepts of open learning [28,29] and action competence [51] which, having elements of different RSP competences (not least futures, participation and action) underscores the need for a blended, holistic model such as that represented by the artist's palette.

\subsection{Assessment}

It is one thing to test knowledge and another to assess skill but to consider them combined alongside, for example, values and capability is quite another challenge. With a pedagogical stance geared towards learner empowerment and autonomy, a formal assessment approach, such as an essay or examination, where the power rests with the educator, seemed inappropriate. As discussed above, different learner-centered approaches were explored including portfolios and various forms of 
peer assessment. The aim here was to achieve examples of "constructive alignment" [65], that is to assess constructivist learning in a manner that encourages the learner to practice the very competences (or learning outcomes) that the course is designed to teach. For example, the portfolio evidence that participants were asked to provide in the UK and Italy encourage a wider reflection on personal and professional roles in light of the concepts being discussed on the program. This in turn enables participants to better grasp the new concepts as they make judgement on their own level of competence and what evidence might help to demonstrate this.

\subsection{Accreditation Models}

An intended outcome for the RSP project was to produce a pan-European qualification for educators of ESD. Over the course of the project, it became evident that this was neither practical nor desirable for four principal reasons.

Firstly, a carefully crafted, competence-based award would not map neatly against the wide range of accreditation templates used across Europe. After an extensive search, the most comprehensive approach was provided by a commercial company but even this did not cover all partner countries. This is related closely to a second issue, that of the nature of potential learners who extend from voluntary youth workers to senior leaders in schools. Consequently, participants could potentially range from ISCED level 3 to level 7 and one style of qualification would not suit this range.

The third challenge is the means by which the RSP competences might be offered within any given institution. With limited time and funding some might prefer a stand-alone program that can be offered as an extra-curricular activity while others might seek to embed the competences within existing programs. To maximize the potential for use by a variety of contexts, it was felt that the most effective approach would be to provide a framework with a rationale, guidance, example activities, and suggested assessment strategies, all of which could be adapted and used flexibly to suit local needs.

Finally, partners agreed that the typical approach to assessing competences, breaking them down into categories such as knowledge, skills, judgements, or values, atomizes learning in a manner that is antithetical to the holistic principles of sustainability. Even as we offer accredited competence-based courses, we must remain mindful of these shortcomings and encourage our learners to be critical of the very means by which they are demonstrating their achievements.

\section{Conclusions}

An accessible framework of ESD competences has been in demand for many years and it was the frustration of project partners' own attempts to use existing frameworks that led to RSP being proposed. In common with many projects, RSP provided a rich learning experience for those involved regardless of the project outputs; however, in this case the project impact has already demonstrated its potential to extend well beyond the original participants.

Further work is required in testing and refining the RSP framework, particularly in the area of assessment. At the time of writing, further European Union funding has been secured and a second three-year phase (RSP II) has begun. This has widened the partnership to include German, Spanish and Swiss (French-speaking) partners.

While the RSP competences were being elaborated far larger processes were in train, not least the launching of the United Nations' Sustainable Development Goals (SDGs) and the SDG-related Education 2030 program of the OECD. RSP partners have been proactive in building synergies with both developments. RSP II includes a specific objective to integrate the SDGs into the RSP framework. Meanwhile the project outputs have been presented to the OECD Education 2030 Secretariat with a view to sharing insights and contributing to the pool of resources available to the Education 2030 process. In addition, the RSP model has been presented to the UNECE ESD Steering Committee and has subsequently been selected as a case study for presentation at the Regional Forum on Sustainable Development for the UNECE Region (March 2019). 
Ultimately, the extent to which RSP or any other framework impacts on the preparation of educators will be determined largely at institutional and government level. That said, in a complex adaptive system such as education, the actions of every individual may register some degree of impact. In the face of potentially overwhelming global challenges, the authors of this paper have set out to contribute to a broader, deeper purpose of education, one in which educators develop citizens with the skills, understanding, and motivation to meet those challenges.

Author Contributions: Conceptualization, P.V., A.d.H., R.M. and A.Z.; Funding acquisition, P.V.; Investigation, P.V., G.A., A.d.H., G.D.G., G.d.V., F.F., C.K.-B., M.K., C.N., R.M., M.R. and A.Z.; Methodology, P.V., G.A., A.d.H., G.D.G., G.d.V., F.F., C.K.-B., M.K., C.N., R.M., M.R. and A.Z.; Project administration, P.V., G.A., A.d.H., F.F., M.R. and A.Z.; Validation, P.V., G.A., A.d.H., G.D.G., G.d.V., F.F., C.K.-B., M.K., M.M., C.N., R.M., M.R. and A.Z.; Writing-original draft, P.V., G.A., A.d.H., G.D.G., G.d.V., F.F., C.K.B., M.K., M.M., C.N., R.M., M.R. and A.Z.; Writing-review \& editing, P.V.

Funding: This research was funded by the European Union Erasmust programme, Agreement Number: 2015-1-UK01-KA203-013720.

Acknowledgments: The authors wish to thank the Erasmus+ UK National Agency (British Council) and the University of Gloucestershire University Funding Office for their support throughout this project.

Conflicts of Interest: The authors declare no conflict of interest.

\section{References}

1. Sterling, S. Assuming the Future: Repurposing Education in a Volatile Age. In Post-Sustainability and Environmental Education: Remaking Education for the Future; Jickling, B., Sterling, S., Eds.; Palgrave: Cham, Switzerland, 2017.

2. Hardoon, D.; Ayele, S.; Fuentes-Nieva, R. An Economy for the 1\%: How Privilege and Power in the Economy Drive Extreme Inequality and How This Can Be Stopped; Oxfam International: Oxford, UK, 2016; Available online: https: / / oxf.am/2FKbYYL (accessed on 26 November 2018).

3. Firth, R.; Winter, C. Constructing Education for Sustainable Development: The Secondary School Geography Curriculum and Initial Teacher Training. Environ. Educ. Res. 2007, 13, 599-619. [CrossRef]

4. Mochizuki, Y.; Fadeeva, Z. Competences for sustainable development and sustainability Significance and challenges for ESD. Int. J. Sustain. Educ. High. Educ. 2010, 11, 391-403. [CrossRef]

5. Spady, W.G. Outcome-Based Education: Critical Issues and Answers; American Association of School Administrators: Arlington, TX, USA, 1994.

6. Burke, J.W. Competency Based Education and Training; Falmer Press: London, UK, 1990.

7. Hodkinson, P.; Issit, M. The Challenge of Competence: Professionalism through Vocational Education and Training; Cassell: London, UK, 1994.

8. Trotter, A.; Ellison, L. Understanding competence and competency. In School Leadership fot the 21st Century. A Competency and Knowledge Approach; Davies, B., Ellison, L., Eds.; Routledge: London, UK, 1997; pp. 54-67.

9. Charlton, P. Leadership-the Human Race: A Guide to Developing Leadership Potential in South Africa; Juta: Cape Town, South Africa, 1993.

10. Meyer, T. Creating Competitions through Competencies: Currency for the 21st Century; Sigma: Pretoria, South Africa, 1996.

11. Weinert, F.E. Concept of competence. A conceptual clarification. In Defining and Selecting Key Competences; Rychen, D.S., Salganik, L.H., Eds.; Hogrefe and Huber: Gottingen, Germany, 2001; pp. 45-66.

12. Adomßent, M.; Hoffman, T. The Concept of Competencies in the Context of Education for Sustainable Development. 2013. Available online: https://pdfs.semanticscholar.org/9ec3/ 118c915b2b11fd1017a1691398346f46af45.pdf (accessed on 3 December 2018).

13. Sleurs, W. Competencies for ESD (Education for Sustainable Development) Teachers, a Framework to Integrate ESD in the Curriculum of Teacher Training Institutes. Comenius 2.1 project 118277-c p-1-2004-b e-Comenius-c 2.1. 2008. Available online: http://www.unece.org/env/esd/inf.meeting.docs/egonInd/8mtg/csct $\%$ 20HandbookExtract.pdf (accessed on 20 November 2018).

14. Barth, M.; Godemann, J.; Rieckmann, M.; Stoltenberg, U. Developing key competencies for sustainable development in higher education. Int. J. Sustain. High. Educ. 2007, 8, 416-430. [CrossRef] 
15. Shephard, K.; Rieckmann, M.; Barth, M. Seeking sustainability competence and capability in the ESD and HESD literature: An international philosophical hermeneutic analysis. Environ. Educ. Res. 2018. [CrossRef]

16. Rychen, D.S.; Salganik, L.H. (Eds.) Key Competences for a Successful Life and a Well-Functioning Society; Hogrefe and Huber: Göttingen, Germany, 2003.

17. Organisation for Economic Co-Operation and Development. The Definition and Selection of Key Competencies: Executive Summary. 2005. Available online: http:/ /www.oecd.org/education/2030/E2030\% 20Position\%20Paper\%20(05.04.2018).pdf (accessed on 3 December 2018).

18. UNECE Learning from Each Other; UNECE: Geneva, Switzerland, 2009.

19. UNESCO. Learning the Treasure within; UNESCO: Paris, France, 1996.

20. United Nations Economic Commission for Europe (UNECE). Learning for the Future: Competences in Education for Sustainable Development, ECE/CEP/ AC.13/2011/6. 2012. Available online: https:// www.unece.org/fileadmin/DAM/env/esd/ESD_Publications/Competences_Publication.pdf (accessed on 8 January 2019).

21. United Nations Economic Commission for Europe (UNECE). Empowering Educators for a Sustainable Future. Tools for Policy and Practice Workshops on Competences in Education for Sustainable Development. 2013. Available online: https:/ / www.unece.org/fileadmin/DAM/env/esd /ESD_Publications/Empowering Educators_for_a_Sustainable_Future_ENG.pdf (accessed on 10 December 2018).

22. Rieckmann, M. Developing Key Competences for Sustainable Development. 2011. Available online: https:/ /www.leuphana.de/fileadmin/user_upload/Forschungseinrichtungen/infu/files/pdf/ vortraege/Rieckmann_Competences_and_Sustainability.pdf (accessed on 26 November 2018).

23. Wiek, A.; Withycombe, L.; Redman, C.L. Moving forward on competencies in sustainability. Environ.-Sci. Policy Sustain. Dev. 2011, 53, 3-13. [CrossRef]

24. Rieckmann, M. Learning to transform the world: Key competences in Education for Sustainable Development. In Issues and Trends in Education for Sustainable Development; Leicht, A., Heiss, J., Byun, W.J., Eds.; UNESCO: Paris, France, 2018.

25. Wiek, A.; Withycombe, L.; Redman, C.L. Key competences in sustainability: A reference framework for academic program development. Sustain. Sci. 2011, 6, 203-218. [CrossRef]

26. Lozano, R.; Merrill, M.Y.; Sammalisto, K.; Ceulemans, K.; Lozano, F.J. Connecting Competences and Pedagogical Approaches for Sustainable Development in Higher Education: A Literature Review and Framework Proposal. Sustainability 2017, 9, 1889. [CrossRef]

27. Lozano, R.; Barreiro-Gen, M.; Lozano, F.J.; Sammalisto, K. Teaching Sustainability in European Higher Education Institutions: Assessing the Connections between Competences and Pedagogical Approaches. Sustainability 2019, 11, 1602. [CrossRef]

28. Bürgener, L.; Barth, M. Sustainability competencies in teacher education: Making teacher education count in everyday school practice. J. Clean. Prod. 2018, 174, 821-826. [CrossRef]

29. Glazer, E.M.; Hannafin, M.J. The collaborative apprenticeship model: Situated professional development within school settings. Teach. Teach. Educ. 2006, 22, 179-193. [CrossRef]

30. Roorda, N. Fundamentals of Sustainable Development; Earthscan: London, UK, 2012.

31. Wiek, A.; Bernstein, M.; Foley, R.; Cohen, M.; Forrest, N.; Kuzdas, C.; Kay, B.; Withycombe Keeler, L. Operationalising competencies in higher education for sustainable development. In Handbook of Higher Education for Sustainable Development; Barth, M., Michelsen, G., Rieckmann, M., Thomas, I., Eds.; Routledge: London, UK, 2015; pp. 241-260.

32. Lang, D.J.; Wiek, A.; Bergmann, M.; Stauffacher, M.; Martens, P.; Moll, P.; Swilling, M.; Thomas, C.J. Transdisciplinary research in sustainability science: Practice, principles, and challenges. Sustain. Sci. 2012, 7 (Suppl. 1), 25. [CrossRef]

33. Mayer, M. Complexity, quality and evaluation: A challenge for Environmental Education. In New Proposals for Action, Proceedings International Meeting of Experts in Environmental Education; Xunta de Galicia y UNESCO: Santiago de Compostela, Spain, 2000.

34. Linstone, H.A.; Turoff, M. (Eds.) The Delphi Method Techniques and Applications; Addison-Wesley: Reading, MA, USA, 1975; p. 3.

35. Réti, M. Challenges about evaluating sustainability in complex science education programs in Hungarian primary schools. Presented at the Post-Conference Research Seminar. Designing a Sustainablie Future through School-Community Collaborations Konferencia, Barcelona, Catalonia, Spain, 21-23 May 2014. 
36. Organisation for Economic Co-operation and Development. Green at Fifteen? How 15-Year-Olds Perform in Environmental Science and Geoscience in PISA 2006; OECD: Paris, France, 2009; Available online: https: / / www.oecd.org/pisa/pisaproducts/42467312.pdf (accessed on 21 December 2018).

37. De Vries, G.; Vare, P.; de Hamer, A. Towards a Workable Set of Educator Competences in Education for Sustainable Development: The RSP Project. In The Learning Teacher Magazine 3/2018; The Learning Teacher Network: Karlstad, Sweden, 2018.

38. Mayer, M.; Farioli, F. Monitoring and Evaluation Plan for the RSP Project; Internal RSP Report; University of Gloucestershire: Cheltenham, UK, 2016.

39. Vare, P. A Rounder Sense of Purpose: Developing and Assessing Competences for Educators of Sustainable Development in Form@re 18:2. 2018. Available online: http://www.fupress.net/index.php/formare/index (accessed on 8 January 2019).

40. RSP. A Rounder Sense of Purpose-Project Website. 2018. Available online: www.aroundersenseofpurpose. eu (accessed on 8 January 2019).

41. Rittel, H.W.J.; Webber, M.M. Dilemmas in a General Theory of Planning. Policy Sci. 1973, 4, 155-169. [CrossRef]

42. Clayton, A.M.H.; Radcliffe, N.J. Sustainability: A Systems Approach; Westview: Boulder, CO, USA, 1996.

43. Sterling, S. Higher Education, Sustainability, and the Role of Systemic Learning. In Higher Education and the Challenge of Sustainability; Corcoran, P.B., Wals, A.E.J., Eds.; Springer: Dordrecht, The Netherlands, 2004.

44. UNECE. Learning for the Future. Competences in Education for Sustainable Development; UNECE: Geneva, Switzerland, 2011. Available online: https://www.unece.org/fileadmin/DAM/env/esd/ESD_ Publications/Competences_Publication.pdf (accessed on 19 November 2018).

45. UNECE. Empowering Educators for a Sustainable Future; UNECE: Geneva, Switzerland, 2013.

46. Chinn, C.; Brewer, W. Knowledge change in response to data in science, religion, and magic. In Imagining the Impossible: Magical, Scientific, and Religious Thinking in Children; Rosengren, K., Johnson, C., Harris, P., Eds.; Cambridge University Press: New York, NY, USA, 2000; pp. 334-371.

47. Chinn, C.A.; Malhotra, B.A. Epistemologically authentic inquiry in schools: A theoretical framework for evaluating inquiry tasks. Sci. Educ. 2002, 86, 175-218. [CrossRef]

48. Ojala, M. Hope and anticipation in education for a sustainable future. Futures 2017, 94, 76-84. [CrossRef]

49. Ryan, R.M.; Deci, E.L. Self-Determination Theory: Basic Psychological Needs in Motivation, Development, and Wellness; Guilford Publications: New York, NY, USA, 2017.

50. Unanue, W.; Vignoles, V.L.; Dittmar, H.; Vansteenkiste, M. Life goals predict environmental behavior: Cross-cultural and longitudinal evidence. J. Environ. Psychol. 2016, 46, 10-22. [CrossRef]

51. Jensen, B.B.; Schnack, K. The Action Competence Approach in Environmental Education. Environ. Educ. Res. 1997, 3, 163-178. [CrossRef]

52. Biesta, G. The Beautiful Risk of Education; Paradigm Publishers: Boulder, CO, USA; London, UK, 2013.

53. Cottrell, S. Critical Thinking Skills: Developing Effective Analysis and Argument; Palgrave: Basingstoke, UK, 2017.

54. Gardner, H. Five Minds for the Future; Harvard Business School Press: Boston, MA, USA, 2006.

55. Thiele, L. Sustainability; Polity: Cambridge, UK, 2013.

56. Dunlap, R.E. The new environmental paradigm scale: From marginality to worldwide use. J. Environ. Educ. 2008, 40, 3-18. [CrossRef]

57. Wegerif, R. Towards a dialogic theory of how children learn to think. Think. Skills Creat. 2011, 6, 179-190. [CrossRef]

58. Costa, A.L.; Kallick, B. Through the Lens of a Critical Friend. Educ. Leadersh. 1993, 51, 49.

59. Mayer, M. A Rounder Sense of Purpose External Evaluation Final Report; Internal RSP Report; University of Gloucestershire: Cheltenham, UK, 2018.

60. Rieckmann, M. Future-oriented higher education: Which key competencies should be fostered through university teaching and learning? Futures 2012, 44, 127-135. [CrossRef]

61. Sterling, S. Sustainable Education, Re-Visioning Learning and Change; Green Books: Dartington, UK, 2001.

62. Wals, A.E.J. Social Learning Towards a Sustainable World: Principles, Perspectives, and Praxis; WAP: Wageningen, The Netherlands, 2007.

63. Vygotsky, L.S. Mind in Society: The Development of Higher Psychological Processes; Harvard University Press: Cambridge, MA, USA, 1978. 
64. Lave, J.; Wenger, E. Situated Learning: Legitimate Peripheral Participation; Cambridge University Press: Cambridge, UK, 1991.

65. Biggs, J.; Tang, C. Teaching for Quality Learning at University—What the Student Does, 3rd ed.; Open University Press/SHRE: Buckingham, UK, 2007. 